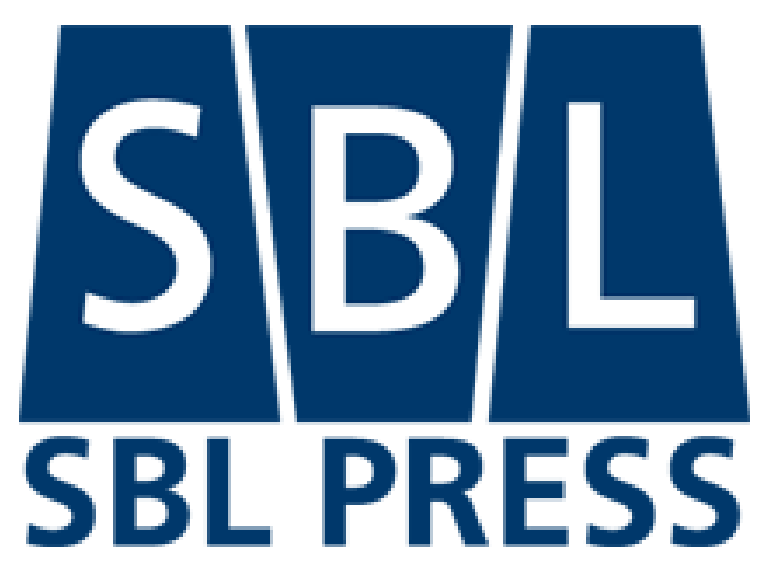

Papias's Prologue and the Probability of Parallels

Author(s): Nevin Climenhaga

Source: Journal of Biblical Literature, 2020, Vol. 139, No. 3 (2020), pp. 591-596

Published by: The Society of Biblical Literature

Stable URL: https://www.jstor.org/stable/10.15699/jbl.1393.2020.8

\title{
REFERENCES
}

Linked references are available on TSTOR for this article. https://ww jstor org/stable/10.15699/jbl.1393.2020.8?seq=1\&cid=pdfreference\#references_tab_contents

You may need to log in to JSTUR to access the linked references.

JSTOR is a not-for-profit service that helps scholars, researchers, and students discover, use, and build upon a wide range of content in a trusted digital archive. We use information technology and tools to increase productivity and facilitate new forms of scholarship. For more information about JSTOR, please contact support@jstor.org.

Your use of the JSTOR archive indicates your acceptance of the Terms \& Conditions of Use, available at https://about.jstor.org/terms 


\title{
Papias's Prologue and the Probability of Parallels
}

\author{
NEVIN CLIMENHAGA \\ nevin.climenhaga@acu.edu.au \\ Dianoia Institute of Philosophy, Australian Catholic University, \\ East Melbourne, Victoria, 3002, Australia
}

\begin{abstract}
Several scholars, including Martin Hengel, R. Alan Culpepper, and Richard Bauckham, have argued that Papias had knowledge of the Gospel of John on the grounds that Papias's prologue lists six of Jesus's disciples in the same order in which they are named in the Gospel of John: Andrew, Peter, Philip, Thomas, James, and John. In "A Note on Papias's Knowledge of the Fourth Gospel" (JBL 129 [2010]: 793-94), Jake H. O'Connell presents a statistical analysis of this argument, according to which the probability of this correspondence occurring by chance is lower than 1 percent. O'Connell concludes that it is more than 99 percent probable that this correspondence is the result of Papias's copying John, rather than chance. I show that O'Connell's analysis contains multiple mistakes, both substantive and mathematical: it ignores relevant evidence; overstates the correspondence between John and Papias; wrongly assumes that, if Papias did not know John, he ordered the disciples randomly; and conflates the probability of A given B with the probability of B given A. In discussing these errors, I aim to inform both Johannine scholarship and the use of probabilistic methods in historical reasoning.
\end{abstract}

Jake H. O'Connell has recently defended an argument, based on a correspondence between the disciples listed in Papias's prologue and those named in John, that Papias was familiar with the Gospel of John. ${ }^{1}$ The relevant text from Papias reads as follows:

I will not, however, shy away from including also as many things from the elders I had carefully committed to memory and carefully kept in memory, along with the interpretations, so as to confirm the truth for you on their account.... But if anyone who had followed the elders ever came along, I would examine the words

${ }^{1}$ Jake H. O'Connell, “A Note on Papias's Knowledge of the Fourth Gospel," JBL 129 (2010): 793-94, https://doi.org/10.2307/25765967. Page references to O'Connell's article will be given in parentheses in the text. 
of the elders-what did Andrew or what did Peter say, or what did Philip, or what did Thomas or James, or what did John or Matthew, or any other of the disciples of the Lord-and what Aristion and John the elder, disciples of the Lord, were saying. ${ }^{2}$

O'Connell notes that the first six of these seven disciples are found in the Gospel of John, and that "Papias lists their names in precisely the order in which these characters are introduced in John" (793). He suggests that either

(1) Papias went through the Gospel of John, noting each time a new disciple was named, and then made sure that the disciples in his prologue were listed in the same order in which they appear in John; [or] (2) Papias listed first the disciples who are named in John 1:35-51 (Andrew, Peter, and Philip) and then the disciples who are named in John 21:2 (Thomas and the sons of Zebedee), omitting Nathanael (who is named in both 1:46 and 21:2) each time. (793-94)

Others have made this argument previously. ${ }^{3}$ O'Connell's contribution is the use of probability theory to analyze its evidential force. I show here that O'Connell's analysis is based on multiple mistakes, both substantive and mathematical. I hope that this correction is instructive for the use of mathematical methods in historical analysis more broadly. ${ }^{4}$

\section{O'Connell writes:}

[I]f it is given that Papias and John are each going to name the same six disciples ... the probability that each will name the same disciples in the same order is $720: 1$. In other words, the odds are 99.86 percent (719/720) that the correspondence is not by chance. This calculation is made by multiplying $1 / 6 \times 1 / 5 \times$ $1 / 4 \times 1 / 3 \times 1 / 2 \times 1 / 1$. That is, the odds that both John and Papias will name Andrew first are 1/6; the odds that both will name Peter second [given that they both name Andrew first] are 1/5; the odds that they will both name Philip third [given that they both name Andrew first and Peter second] are 1/4; and so on. When we multiply all six numbers together we arrive at 1/720. (794)

${ }^{2}$ Papias apud Eusebium, Hist. eccl. 3.39.3-4 (emphasis added). Translation from Stephen C. Carlson, ed. and trans., Papias of Hierapolis: Exposition of Dominical Oracles; The Fragments, Testimonia, and Reception of a Second-Century Commentator, OECT (Oxford: Oxford University Press, forthcoming).

${ }^{3}$ O'Connell cites Martin Hengel, The Johannine Question (London: SCM, 1989), 17-19; R. Alan Culpepper, John the Son of Zebedee: The Life of a Legend, Studies on Personalities of the New Testament (Columbia: University of South Carolina Press, 1994), 111-12; and Richard Bauckham, Jesus and the Eyewitnesses: The Gospels as Eyewitness Testimony (Grand Rapids: Eerdmans, 2006), 417-19. O'Connell's mathematical analysis has subsequently been cited as support for this argument by Richard Bauckham, "Did Papias Write History or Exegesis?, JTS 65 (2014): 463-88, here 463 n. 1; as well as by Anthony J. Blasi, Social Science and the Christian Scriptures: Sociological Introductions and New Translation, 3 vols. (Eugene, OR: Wipf \& Stock, 2017), 3:111.

${ }^{4}$ For a general introduction to the concept of probability and its applications in empirical reasoning, see Nevin Climenhaga, "The Concept of Probability Is Not as Simple as You Think," Aeon, 26 February 2019, https://aeon.co/ideas/the-concept-of-probability-is-not-as-simple-asyou-think. 
Noting that $719 / 720 \approx 99.86$ percent, O'Connell concludes from this "that the odds that this correspondence is not by chance are greater than 99 percent" (794).

A few notes. First, when O'Connell says "odds," he means "probability." The probability that a hypothesis is true is a number between 0 and 1 . The odds that a hypothesis is true is a ratio: it is the ratio of the probability that it is true to the probability that it is false. So if a hypothesis has "even odds" of being true, its probability is 50 percent, and its odds are $1: 1$. If the probability that it is true is $1 / 720$, then the odds that it is true are $(1 / 720):(719 / 720)=1: 719 .{ }^{5}$ Second, when O'Connell says that the probability that Papias and John will name the disciples in the same order is $720: 1$, he presumably means to say that this probability is $1 / 720$.

Setting aside terminology and transpositions, O'Connell makes four major errors. First, his calculation wrongly presupposes that Papias and John both place six disciples in the same order. But John 21:2 does not list James and John by name; instead, it refers to the "sons of Zebedee," which implies no order between James and John. This means that there are two ways for Papias's list to correspond to the Gospel of John: by naming the disciples in the order it actually does, or by naming them in the same order except with John preceding James. If these both have probability $1 / 720$, the probability of Papias and John corresponding in one of these ways is then $2 / 720=1 / 360$.

Second, both of these calculations assume that all orders are equally likely given that Papias was not familiar with John. This assumption is false. If Papias was not relying on John, the two may have common influences, so that the correspondence of Papias's order with John is not solely the result of random chance. O'Connell writes that no one has proposed a common source to explain the correspondence. But even if no common source fully explains the correspondence, plausible common sources could partially explain it, so that the remaining coincidences are much less extreme. Papias and John could, for example, both have relied on the Gospel of Matthew and partially reproduced orderings found in Matthew and deviated from or added to them in similar ways. ${ }^{6}$ Nor should we assume that the only possible common influences on John and Papias are other textual orderings. Both authors may also have been influenced by salient historical details that make it natural to mention certain disciples together, such as fraternal relationships. As an illustration, suppose that Papias is certain to group Andrew and Peter together and group James and John together, but that his ordering is otherwise random. Then

${ }^{5}$ For further discussion of odds and the usefulness of the concept, see E. T. Jaynes, Probability Theory: The Logic of Science (Cambridge: Cambridge University Press, 2004), chapter 4.

${ }^{6}$ Here is a comparison of the order in which the disciples are listed in Papias's prologue and in Matthew 10:2-3 (with ellipses for the five disciples not mentioned by Papias):

Matthew: Peter, Andrew, James, John, Philip, ..., Thomas, Matthew, ...

Papias: $\quad$ Andrew, Peter, Philip, Thomas, James, John, Matthew

For further discussion, see Dennis R. MacDonald, Two Shipwrecked Gospels: The Logoi of Jesus and Papias's Exposition of Logia about the Lord, ECL 8 (Atlanta: Society of Biblical Literature, 2012), 17 n. 26. 
the probability is $1 / 4 \times 1 / 3 \times 1 / 2 \times 1 / 1=1 / 24$ that his order is as follows: Andrew + Peter, Philip, Thomas, James + John. The probability that he also lists Andrew prior to Peter is $1 / 2$, and the probability of the overall correspondence with the Gospel of John is then $1 / 24 \times 1 / 2=1 / 48$.

Third, and most importantly, O'Connell's conclusion that the "final" probability "that this correspondence is not by chance" is higher than 99 percent (794) does not follow from his premise that the probability of this correspondence occurring, given chance, is lower than 1 percent. O'Connell equates the probability of the order corresponding, given chance, with the probability of chance, given that the order corresponds. These two, however, are not equivalent. An analogy: suppose you know that I either rolled a 100-sided die at random or placed it intentionally with 47 facing upward. You look and see that in fact, 8 is facing upward. The probability of this result given chance is 1 percent. But it does not follow that the probability of chance given this result is 1 percent. The probability of chance given this result is 100 percent, because you know that if the result were not due to chance, 8 would not be facing upward.

In order to calculate the probability of a hypothesis given our evidence-its "posterior probability," in the Bayesian lingo-we need three things: the probability of the hypothesis apart from the evidence (its "prior probability"), the probability of the evidence given the truth of the hypothesis, and the probability of the evidence given the falsity of the hypothesis. ${ }^{7}$ O'Connell's premise concerns the last of these terms - the probability of the evidence given that Papias did not rely on John. But we cannot get from there to a conclusion about the posterior probability that Papias relied on John without considering the other two factors as well. This error-focusing only on the probability of the evidence given chance, and ignoring the probability of the evidence given the alternative hypothesis and the prior probability of the alternative hypothesis-is exactly the error many scientists make in misinterpreting $p$-values. ${ }^{8}$ In attempting to apply statistical tools to biblical studies, O'Connell has replicated a common statistical fallacy.

${ }^{7}$ Here is the equation, where $\mathrm{H}=$ our hypothesis, $\mathrm{E}=$ our evidence, and $\mathrm{K}=$ our background knowledge. (Read " $\mathrm{P}(\mathrm{A} \mid \mathrm{B})$ " as "the probability of A given B".)

$$
\frac{P(H \mid E \text { and } K)}{P(\text { not }-H \mid E \text { and } K)}=\frac{P(H \mid K)}{P(\text { not }-H \mid K)} \quad \times \frac{P(E \mid H \text { and } K)}{P(E \mid \text { not }-H \text { and } K)}
$$

This is the Odds Form of Bayes's theorem. It says that the odds of $\mathrm{H}$ given $\mathrm{E}$ and $\mathrm{K}$ equals the odds of $\mathrm{H}$ given just $\mathrm{K}$ times the ratio of the probability of $\mathrm{E}$ given $\mathrm{H}$ and $\mathrm{K}$ to the probability of $\mathrm{E}$ given not- $\mathrm{H}$ and $\mathrm{K}$. This last ratio is called the "Bayes's factor" and measures the degree to which $\mathrm{E}$ confirms $\mathrm{H}$-that is, how much it raises the odds of $\mathrm{H}$ (relative to our background knowledge $\mathrm{K}$ ). For further discussion of when and how to apply Bayes's theorem, see Nevin Climenhaga, "The Structure of Epistemic Probabilities," Philosophical Studies 77 (2020): esp. $\$ \$ 3.4$ and 4, https://doi .org/10.1007/s11098-019-01367-0.

${ }^{8} \mathrm{~A} p$-value is, roughly, the probability of getting an experimental result this extreme given chance. In the social and medical sciences, a $p$-value of 0.05 or below is standardly used as a 
If we set aside the prior probability of our hypothesis, Bayes's theorem tells us that to determine how some evidence changes the probability of that hypothesis, we need to know not only how probable the evidence is given that the hypothesis is false but also how probable it is given that the hypothesis is true. That is, we need to compare how strongly the hypothesis and its negation predict the evidence. The degree to which our evidence confirms the hypothesis is determined not solely by the improbability of the evidence given that the hypothesis is false but by how much greater its probability is given that the hypothesis is true.

In the case at hand, what this means is that the improbability of Papias just happening to mention the disciples in a way that looks like following John needs to be weighed against the improbability of his following John in exactly this way. For it is not certain that, if Papias is aware of the Gospel of John, he would list these six disciples in the order he did. He could easily be aware of John and yet list the disciples in an order different from that in John. Even if he intentionally aims to follow John's order, he need not pick this order. For example, while only Andrew, Peter, and Philip are named in John 1:35-51, this passage mentions an unnamed second disciple of John the Baptist, along with Andrew. This disciple may be John himself, so that Papias could have instead listed John along with Andrew at the beginning of the list, and done so with the intention of following the Gospel of John's ordering.

Finally, in calculating the impact of our evidence on a hypothesis, we need to be sure we are considering all the relevant parts of the evidence. In the case at hand, if we are calculating the impact of the fact that Papias lists Andrew, Peter, Philip, Thomas, James, John, and Matthew in that order, we need to take into account not only the correspondence of order among the first six of these in Papias and John but also the absence of Matthew in John, and the absence of Nathanael, Nicodemus, and Judas not Iscariot in Papias, even though all three are named in John (the first in the passages referenced above, and the second and third in John 3:1 and John 14:22, respectively). ${ }^{9}$ These further facts are less probable given that Papias relied on John than otherwise and are accordingly some evidence against this hypothesis,

threshold for "statistical significance," with results with $p$-values below this threshold considered significant and results with $p$-values above this threshold considered insignificant. In recent years scientists and statisticians have become increasingly concerned with confusions about and misapplications of $p$-values, including the conflation of the $p$-value with the probability of chance given the experimental result. See John P. A. Ioannidis, "Why Most Published Research Findings Are False," PLOS Medicine 2 (2005): art. e124, https://doi.org/10.1371/journal.pmed.0020124; Joseph P. Simmons, Leif D. Nelson, and Uri Simonsohn, "False-Positive Psychology: Undisclosed Flexibility in Data Collection and Analysis Allows Presenting Anything as Significant," Psychological Science 22 (2011): 1359-66; Ronald L. Wasserstein, "ASA Statement on Statistical Significance and P-values," American Statistician 70 (2016): 131-33.

${ }^{9}$ See MacDonald, Two Shipwrecked Gospels, 17 n. 26. 
taken in themselves. ${ }^{10}$ Taking these facts together with the order of the disciples, it is an open question whether, on balance, Papias's list is evidence that he was familiar with John.

O'Connell's probabilistic analysis goes wrong at several points: he does not take into account all the evidence (including points on which Papias and John do not agree); he does not accurately summarize the evidence he does consider (John does not order the sons of Zebedee); his mathematical model relies on a false assumption (that Papias would order the six disciples randomly if he is not relying on John); and he conflates distinct mathematical terms (the probability of our evidence given chance and the probability of chance given our evidence). Mathematical methods can usefully clarify informal reasoning when they are applied carefully. But when applied carelessly, they serve only to amplify errors. I hope that my discussion of the errors in O'Connell's analysis can help future applications of probability theory to historical reasoning avoid similar errors.

${ }^{10} \mathrm{O}$ Connell also mentions-correctly—-the need to take into account the fact that Andrew, Peter, Philip, Thomas, James, and John are mentioned in both Papias and John (in any order). But he makes the same error here as with the evidence of the concurrence of order-he considers only the probability of these six being present in both texts by chance, and not the probability of this given that Papias was relying on John. These probabilities similarly need to be weighed against each other. 